\title{
Habitat Differences Affect the Nuclear Morphology of the Erythrocytes and the Hepatic Melanin in Leptodactylus Fuscus (Anura) in the Brazilian Cerrado Savanna
}

Rhayane Alves Assis ( $\square$ rhayanealves1@hotmail.com )

Universidade Estadual Paulista: Universidade Estadual Paulista Julio de Mesquita Filho https://orcid.org/0000-0001-6750-5490

Wadson Rodrigues Rezende

Universidade Estadual Paulista: Universidade Estadual Paulista Julio de Mesquita Filho

Cirley Gomes Araújo dos Santos

Instituto Federal de Educação Ciência e Tecnologia Goiano: Instituto Federal Goiano

Marcelino Benvindo-Souza

Universidade Federal de Goias

Nathan Pereira Lima Amorim

Instituto Federal de Educação Ciência e Tecnologia Goiano: Instituto Federal Goiano

Rinneu Elias Borges

Universidade de Rio Verde - Campus Rio Verde: Universidade de Rio Verde

Lilian Franco-Belussi

Universidade Federal de Mato Grosso do Sul

Classius De-Oliveira

Universidade Estadual Paulista: Universidade Estadual Paulista Julio de Mesquita Filho

Lia Raquel de Souza Santos

Instituto Federal Goiano

\section{Research Article}

Keywords: Agriculture, Anurans, Erythrocytic nuclear abnormalities, Hepatic melanin, Micronucleus,

Soybean cultivation.

Posted Date: February 15th, 2021

DOI: https://doi.org/10.21203/rs.3.rs-172541/v1

License: (a) This work is licensed under a Creative Commons Attribution 4.0 International License. Read Full License 
Page $2 / 23$ 


\section{Abstract}

The sensitivity of anuran to the effects of habitat destruction and contamination has led to a preoccupying global decline in their populations. Morphological biomarkers such as micronuclei and other erythrocyte nuclear abnormalities (ENAs) and the occurrence of hepatic melanin can be used to evaluate the effects of habitat impacts. In the present study, these two procedures were combined for the in situ assessment of the effects of soybean cultivation on the grassfrog, Leptodactylus fuscus. Specimens were also collected from a protected area to provide a control (non-agricultural environment). The frequency of some nuclear abnormalities in the animals from the soybean plantation was much higher than the control, specifically, micronuclei were 3.6 times more frequent, while lobulated nuclei were 3.4 times more frequent, and reniform nuclei, four times more common. The combined analysis of all the ENAs also revealed a frequency approximately 1.4 times higher in the animals from the soybean plantation, in comparison with the protected area. Smaller areas of hepatic melanin were observed in the specimens from the soybean plantation. These results provide further evidence of the sensitivity of anurans to habitat impacts, and indicate that animals found in soybean plantations are susceptible to systematic alterations of the cells.

\section{Introduction}

Anuran amphibians play an important role in both aquatic and terrestrial communities, where they may act as indicators of the effects of anthropogenic impacts (Böll et al. 2013; Green et al. 2019). Anurans may also play an important role in agroecosystems, given that they include some of the principal natural predators of agricultural pests, worldwide (Arcaute et al. 2014). However, amphibians are one of the planet's most threatened groups of animals, with populations declining rapidly in almost all parts of the world (Stuart et al. 2004; Ficetola and Maiorano 2016; Carvalho et al. 2019). This decline is due to the spread of diseases (Vredenburg et al. 2010), habitat modifications (Blaustein et al. 2011), the introduction of exotic species (Collins 2010), increasing UV radiation (Franco-Belussi et al. 2018), and the increasingly widespread use of pesticides (Arcaute et al. 2014; Pérez-Iglesias et al. 2016; Borges et al. 2019a; Carvalho et al. 2019, Benvindo-Souza et al. 2020).

Multiple stressors for amphibians may arise simultaneously in agricultural environments, including habitat fragmentation (Prado and Rossa-Feres 2014) and the loss of vegetation cover from the margins of bodies of water (Silva et al. 2012a), which results in an increase in UV radiation (Lipinski et al. 2016) and the distance between forest fragments and the ponds in which many amphibian species breed (Silva et al. 2012b). The application of pesticides contaminates not only the soil, but also bodies of water, either directly or indirectly (Lajmanovich et al. 2014), causing shifts in the physical-chemical parameters of the water (Babini et al. 2015). A number of studies have demonstrated the occurrence of mutagenic and genotoxic damage in anurans related to the environmental degradation caused by agricultural practises (Babini et al. 2015, Pollo et al. 2018, Gonçalves et al. 2019; Borges et al. 2019b). 
The micronucleus (MN) test in ecotoxicological studies has become a standard procedure due to its simplicity, high sensitivity, and reliability, with the results becoming available rapidly (Fenech 2000; CruzEsquivel et al. 2017). In addition to micronuclei, other erythrocyte nuclear abnormalities (ENAs) have been associated with the processes of cell division and death (Pollo et al. 2015). These abnormalities include lobed and notched nuclei, and binucleated cells (Pollo et al. 2015; Pérez-Iglesias et al. 2016; Mesak et al. 2018).

In addition to these nuclear anomalies, melanomacrophages have been used as morphological biomarkers of the impact of environmental stressors such as UV radiation (Franco-Belussi et al. 2016), benzo[a]pyrene (Fanali et al. 2018), increasing temperatures (Santos et al., 2014), and the intensification of agricultural activities (Franco-Belussi et al. 2020). Melanomacrophages are pigmented cells with phagocytic activity that are found in the hematopoietic organs, such as the liver and spleen, of ectothermic vertebrates (Agius 1980; Fishelson 2006; Franco-Belussi et al. 2013; Santos et al. 2014). These cells produce and store melanin, which in turn absorbs and neutralizes free radicals and other toxic agents (Zuasti et al. 1989; Fanali et al. 2018).

These biomarkers were used to investigate potential environmental impacts in the South American whitelipped grassfrog, Leptodactylus fuscus (Schneider, 1799), a species native to the Brazilian Cerrado savanna biome. This medium-sized frog (males $=42.8 \pm 4.0 \mathrm{~mm}$; females $=43.6 \pm 4.4 \mathrm{~mm}$; Sugai et al. 2012) occurs throughout much of South America (Frost 2019) and is typical of open habitats (Wynn and Heyer 2001; Sugai et al. 2012). As agricultural frontiers are expanding in South America, especially in Brazil, at an unprecedented rate (Dias et al. 2016), there is an urgent need for in situ studies to determine the impacts of environmental factors related to agricultural practises (Pollo et al. 2017), especially in key biomes, such as the Brazilian Cerrado. In this context, the present study investigated the effects of soybean cultivation on the anuran species $L$. fuscus through the analysis of micronuclei and other ENAs, combined with the levels of hepatic melanin. It should be noted that this is the first in situ study to apply these two techniques simultaneously to the monitoring of natural anuran populations in agricultural areas.

\section{Materials And Methods}

\section{Study area and specimen collection}

The present study was carried out in two areas of the Brazilian Cerrado biome that have distinct histories of land use. The agricultural environment selected for the study was located in the municipality of Rio Verde, in southwestern Goiás, a state in Brazil's Midwest region. This municipality is considered to be the state's principal producer of soybean (IMB 2019) and prior to 2017, it ranked eighth in the national ranking of soybean exporting municipalities (IBGE 2017). Rio Verde thus represents an environment with a high probability of genotoxic impacts on the resident organisms (Borges et al. 2019b). In this environment, 10 adult male Leptodactylus fuscus were collected on a single night in November 2018, during the soybean planting period, through an active nocturnal search. The animals were all collected in 
the vicinity of a single temporary pond of approximately $2 \mathrm{~m} \times 5 \mathrm{~m}$, and $15 \mathrm{~cm}$ in depth, located in the middle of a soybean plantation ( $\left.17^{\circ} 47.742^{\prime} \mathrm{S}, 051^{\circ} 06.089^{\prime} \mathrm{W}\right)$. There are sparse fragments of forest in the surrounding area, but no other bodies of water nearby, and there is vegetation in the water. Data obtained from the NASA Prediction of Worldwide Energy Resources (NASA POWER) website (https://power.larc.nasa.gov/\#dataaccess) show that the mean minimum temperature of this point in 2018 was approximately $17.86^{\circ} \mathrm{C}$, the maximum temperature was almost $28.77^{\circ} \mathrm{C}$, precipitation was 3.51 $\mathrm{mm} /$ day, and the incidence of sunlight was $5.11 \mathrm{Kw} / \mathrm{h} / \mathrm{m}^{2} /$ day.

Another 10 adult male L. fuscus were collected by active night searching in the Emas National Park (ENP) in December 2018. The ENP, a federal conservation unit with an area of approximately 132,000 hectares, is located in southwestern Goiás, in the municipalities of Mineiros and Chapadão do Céu, and in the neighbouring area of the state of Mato Grosso do Sul, in the municipality of Costa Rica (ICMBio 2019). This area is relatively flat, and encompasses different Cerrado formations, such as grassland, shrubby savanna, and riparian forests (ICMBio 2019). In this environment, the specimens were collected on a single night from a large humid area close to a body of water located at least $10 \mathrm{~km}$ from the outer perimeter of the national park $\left(18^{\circ} 06.990^{\prime} \mathrm{S}, 052^{\circ} 55.024^{\prime} \mathrm{W}\right)$. At the collection site, there is a predominance of typical Cerrado shrubby savanna vegetation, with sparse and poorly developed shrubs and herbaceous plants (ICMBio 2019). The mean minimum temperature recorded for the location in 2018 was approximately $18.18^{\circ} \mathrm{C}$, the mean maximum temperature was around $29.29^{\circ} \mathrm{C}$, mean precipitation was $3.15 \mathrm{~mm} /$ day and insolation was $5.10 \mathrm{Kw} / \mathrm{h} / \mathrm{m}^{2} /$ day (data obtained from the NASA POWER website).

All the specimens were taken to the Animal Biology Laboratory of the Goiano Federal Institute in Rio Verde, where the analyses were conducted. The total weight each specimen was determined using a precision analytical balance and the snout-vent length was recorded using a digital caliper $(0.01 \mathrm{~mm}$ precision). The characteristics of the matrix surrounding each sampling point were recorded within a radius of $1 \mathrm{~km}$ (Fig. 1). The ENP is covered (100\%) in natural vegetation, with grassland and savannah typical of the Cerrado biome, while the soybean plantation is dominated by crops (92.59\%), with only $7.41 \%$ of natural vegetation cover.

\section{Ethical and sampling statement}

For this study, licenses for the collection of specimens and animal experimentation were obtained from the Chico Mendes Institute for Biodiversity Conservation (ICMBio), under protocol 62687-1, and the Goiano Federal Institute Ethics Committee on the Use of Animals (CEUA/IFGoiano) under protocol number 6643030518.

\section{Micronuclei and other erythrocyte nuclear abnormalities}

After collection, the animals were euthanized by immersion in the anesthetic Benzocaine $(5 \mathrm{~g} / \mathrm{L})$. An abdominal incision was then made, from which the circulating blood cells of the abdominal cavity were obtained with the aid of a heparinized needle and syringe $(25 \mathrm{~mm} \times 0.7 \mathrm{~mm})$. Two blood slides were 
prepared per animal, which were fixed in cold methanol for 20 minutes and then stained with Giemsa solution (5\%) in tap water for 12 minutes (Vera-Candioti 2010). A total of 2000 cells per animal were analyzed under an optical microscope (Laborana LAB-1001TB) attached to a digital camera (Laborana 3.0Mp), using 100x magnification (Cruz-Esquivel et al. 2017).

The criteria used to identify micronuclei were (a) staining intensity equal to that of the principal nucleus of the cell, but with a smaller diameter, (b) rounded shape unconnected to the principal nucleus, and (c) no overlap with the principal nucleus and located within the cytoplasm (Fenech 2000). The other ENAs quantified in the analyses were binucleated cells, nuclear buds, anucleated cells, lobed nuclei, notched nuclei, reniform (or kidney shaped) nuclei, and segmented nuclei, as described in our recent review (Benvindo-Souza et al. 2020). The data were presented as standard frequencies for each anomaly and for the whole set of ENAs (Pollo et al. 2015; Borges et al. 2019b).

\section{Hepatic melanin}

For the histological analyses, liver fragments were extracted from each L. fuscus specimen, weighed on a precision analytical balance, and fixed in metacarn (60\% methanol, $30 \%$ chloroform, and $10 \%$ acetic acid) for 3 hours at $4^{\circ} \mathrm{C}$. These samples were then dehydrated in an increasing alcohol series and embedded in historesin (Leica-historesin embedding kit) for the extraction of $2 \mu \mathrm{m}$ sections using a Leica RM 2265 microtome (Switzerland). These sections were placed on slides, stained with Hematoxylin-Eosin (HE), and photographed under a Leica DM4 B microscope with a 20x magnification attached to an image capture system (Leica DMC 4500). Hepatic pigmentation was quantified based on color intensity, using the Image Pro-Plus Media-Cybernetics Inc. program (version 6.0). A total of 25 random histological fields were photographed and analyzed in each specimen. The procedures followed the protocols of Santos et al. (2014), Franco-Belussi et al. (2016), and Fanali et al. (2018).

\section{Water quality}

Water samples were collected from both study sites (Rio Verde and the ENP) for physical-chemical analyses. The samples were collected in Rio Verde in November 2018 at approximately 20:00 $\mathrm{h}$ and in the ENP in December 2018 at the same time, and were then sent to the laboratory of analysis within 24 hours of collection. One liter of water was collected from approximately $5 \mathrm{~cm}$ below the water surface of a single pond close to the study site and on the same day that the animals were collected in each environment. The samples were stored in individual amber borosilicate glass flasks at a temperature of $<4^{\circ} \mathrm{C}$ and sent to the Germinar Agroanálises \& Ambiental laboratory in Rio Verde, Goiás, Brazil, for the quantification of carbamate, organochlorine, and organophosphate pesticides. The following substances were analyzed: 2. 4-D + 2. 4. 5-T, Alachlor; Aldicarb + Aldicarb-sulfone + Aldicarb-sulfoxide, Aldrin + Dieldrin, Atrazine, Carbendazim + Benomyl, Carbofuran; Chlordane (Cis + Trans), Chlorpyrifos + Chlorpyrifos-Oxon, DDDT, Diuron, Endosulfan (Alpha + Beta + Sulfate), Endrin, Glyphosate + Ampa, Lindane, Mancozeb, Metamidophos, Metolachlor, Molinate, Methyl Paration, Pendimethalin, Permethrin, Profenofos, Simazine, Tebuconazole, Terbufos, and Trifluralin. All of these compounds can be found in agricultural areas, either after recent application or in residual form from previous land use. The analyses 
were conducted according to the procedures outlined in Standard Methods for the Examination of Water and Wastewater, 23rd edition. The parameters were assessed based on the standards defined by CONAMA resolution number 357/2005 - Class II and decree 1,745/1979.

The temperature, $\mathrm{pH}$, dissolved oxygen, conductivity, resistivity, salinity, and total dissolved solids of the water of each study pond were measured in situ using a portable multi-parameter Bante900P apparatus. These measurements were conducted on the day of the collection of the animal specimens at each site, at approximately 20:00h.

\section{Statistical analyses}

The MN and ENA data, and the melanin scores are presented as means \pm standard deviation. The MN and ENA frequencies and the area of melanin were compared systematically between the two study areas (soybean plantation and the ENP). Prior to the analyses, the homogeneity of the variances was evaluated using Levene's test, and the data were (Log10) transformed to homogenize the variances, as appropriate. Student's $t$ (Pollo et al. 2017) was applied to the parametric data (micronuclei, segmented nucleus, reniform nuclei, notched nuclei, anucleated cells, nuclear buds, binucleated cells, total ENAs, and the area of hepatic melanin), while Mann Whitney's U was applied to the nonparametric data (lobed nuclei). A multiple Pearson correlation analysis was applied to verify the existence of a correlation between the frequency of MNs, other ENAs, and the area of hepatic melanin in each environment. A $p<0.05$ value was considered significant in all analyses.

\section{Results}

\section{Water quality}

The presence of agrochemicals was not detected in the water samples collected from either study environment (Supplementary Material 1). The water parameters recorded in situ in both environments are shown in Table 1. The ENP pond had a neutral $\mathrm{pH}$, whereas that in the soybean plantations acidic. The highest dissolved oxygen concentration was recorded in the ENP, while the highest values of all the other parameters were recorded in the soybean plantation.

\section{Micronuclei and other erythrocyte nuclear abnormalities}

In addition to micronucleated cells, other ENAs were found in the L. fuscus erythrocytes, such as reniform, lobed, notched, and segmented nuclei, anucleated cells, nuclear buds, and binucleated cells. The frequencies of MNs and other ENAs found in each environment are shown in Fig. 2, as a percentage per 2000 erythrocytes. A significantly higher frequency ( $t=3.095 ; p<0.05$; Fig. 3; Table 2$)$ of MNs was recorded in the specimens collected in the soybean plantation in comparison with the ENP. When all the ENAs were considered together, a significantly higher frequency $(t=2.134 ; p<0.05 ;$ Fig. 3$)$ was also found in the soybean plantation in comparison with the ENP. There were also significantly more cells with lobed 
$(U=20.000 ; p<0.05$; Table 2$)$ and reniform nuclei $(t=5.077 ; p<0.05$; Table 2$)$ in the soybean plantation environment when these abnormalities were assessed separately.

\section{Hepatic melanin}

The area occupied by melanin in the liver tissue of individuals of $L$. fuscus was significantly smaller ( $t=$ -22.886; $p<0.05$ ) in the specimens collected in the soybean plantation in comparison with the ENP (see Figures 4 and 5). In the L. fuscus specimens collected in the ENP, melanin covered approximately $3.08 \%$ of the total area of the tissue, whereas in the specimens from the soybean plantation, it covered only $0.93 \%$.

No correlation was found between the frequency of MNs and the area of melanin in the specimens from either the ENP $(r=-0.000 ; p>0.05)$ or the soy plantation $(r=-0.366 ; p>0.05)$. A similar lack of correlation was found between the ENAs (all types combined) and the area of melanin in the specimens from the $\operatorname{ENP}(r=0.222 ; p>0.05)$ and the soybean plantation $(r=-0.523 ; p>0.05)$.

\section{Discussion}

\section{Theenvironmental and biologicalresponses of the anurans}

The results of the present study indicate a clear effect of agriculture on anurans (Fig. 1), as indicated by the reduced coverage of native vegetation within a radius of $1 \mathrm{~km}$ of the soybean pond. Leptodacy/us fuscus is considered to be a generalist species well adapted to changes in habitat, and is known to be a colonizer of degraded habitats (Sugai et al. 2012). Despite this, the environmental stressors found in the agricultural landscape appeared to have provoked significant changes in the blood parameters and liver melanin of the frog specimens in comparison with the natural environment (ENP).

The natural, relatively open conditions of the Cerrado savanna, and the absence of extensive forest cover probably determined the similar climatic conditions recorded in the two areas during the study period (2018), although the ENP had much greater vegetation cover and more extensive wetlands. The pH and temperature of the water are known to influence the toxicity of many pollutants (Hoffman et al. 2010; Pollo et al. 2017), while for amphibians, the ideal pH for healthy development ranges between 6.3 and 7.7 (García and Fontúrbel 2003; Babini et al. 2015; Pollo et al. 2017). The pH recorded in the ENP (7.41) would thus have been adequate for amphibians, whereas that recorded in the soybean plantation (5.38) was excessively acidic. The higher conductivity, total dissolved solids, and salinity recorded in the soybean plantation may have been the result of a process of mineralization provoked by the agricultural practises implemented at this site (Gatica et al. 2012; Babini et al. 2015). High salinity, in particular, may be especially deleterious for organisms dependent on freshwater environment, given that need to maintain an internal osmotic balance (Pollo et al. 2017). High salinity can cause osmoregulatory mechanisms to collapse, which may result in cell damage or even death (Cañedo et al. 2013; Pollo et al. 2017). 
As only $0.1 \%$ of pesticides reach the target organism (Pimentel 1995), farmland soils are commonly contaminated by these chemicals (Leeb et al. 2020). Pignati et al. (2017) alerted that the planting of soybean in Brazil is the activity that most uses pesticides and that the municipality of Rio Verde is one of the ten municipalities that most consume pesticides in Brazil, with a mean of 17.7 liters of agrochemicals being applied per hectare. In the context of the present study, as the adult frogs are post-metamorphic animals, the specimens collected in the plantation may have been exposed to contaminated soil for long periods.

\section{Micronuclei and other nuclear abnormalities}

A significant higher frequency of micronuclei (MNs) was recorded in the L. fuscus specimens from the soybean plantation in comparison with those from the ENP. The formation of MN is known to be a result of the action of genotoxic agents that generate lesions in the DNA (Fenech 2000; Pollo et al. 2015) or as a product of the removal of excess material from the main nucleus, leading to genomic instability (PrietoGarcía et al. 2007; Pollo et al. 2015). A similar pattern has been recorded in previous in situ studies of anurans, both larvae and adults, in habitats disturbed by agricultural practises (Pollo et al. 2015; Babini et al. 2015; Cruz-Esquivel 2017; Borges et al. 2019b). These findings highlight the importance of this type of study for the assessment of the health of populations inhabiting disturbed environments (Hoffman et al. 2003). As in situ studies are potentially influenced by the interaction of multiple stressors (Pollo et al. 2017), it is important to note that the higher temperatures typically found in open farmland may increase the toxic effects of agrochemicals (Hoffman et al. 2003). In the present study, the temperature of the water recorded in the soybean plantation was approximately $12^{\circ} \mathrm{C}$ higher than that recorded in the ENP, which may have contributed to the high frequency of MNs recorded in this environment.

It is also important to note here that the micronucleus test detects late adverse effects (Marquis et al. 2009), which implies that the MNs and other ENAs recorded in the specimens from the soybean plantation may reflect long-term genotoxic effects. As pesticides are applied during the planting of crops, the failure to detect these substances in the water samples may reflect the diluting effects of the rainfall in the region, which may wash the substances out of the soil over time. A number of experimental studies have also demonstrated the formation of MNs in larval anurans in response to exposure to agrochemicals (Mesak et al. 2018; Pérez-Iglesias et al. 2019). Experimental studies of the effects of pesticides on the formation of MNs in adult anurans are less common, however, although Pérez-Iglesias et al. (2016) found evidence of the influence of Glyphosate, one of the world's most widely-used herbicides, on the frequency of MNs and hepatic melanomacrophages in anurans.

In the present study, a higher frequency of ENAs was also found in the specimens from the soybean plantation. Although the formation of these anomalies is not fully understood (Benvindo-Souza et al. 2020), it does appear to reflect adverse reactions in the cells or control mechanisms used to eliminate cells with damaged DNA (Fijan 2002). The lobed and reniform nuclei do appear to be related to the precursors of micronuclei and binucleated cells, however (Araújo et al. 2019). Lobed nuclei have been observed in response to exposure to environmental contaminants in a number of anuran studies 
(Lajmanovich et al. 2014; Pollo et al. 2015; Babini et al. 2016; Pérez-Iglesias et al. 2018). Borges et al. (2019b) detected an increase in the frequency of reniform nuclei in tadpoles collected from an agricultural environment in comparison with those collected in the ENP, which is consistent with our results. Binucleated cells, like MNs, are related to cell division (Baršienè et al. 2010; Pollo et al. 2015), while nuclear bud is related to the amplification or polyploidization of the DNA, with excess genetic material being removed through the subsequent formation of MNs (Prieto-García et al. 2007; Pollo et al. 2015). Anucleated cells are considered to be a response to stressful situations, such as changes in the diet, pathologies, and metabolic damage (Lajmanovich et al. 2014). These and the other ENAs, such as notched and segmented nuclei, are thought to be provoked in anurans by pesticides (Lajmanovich et al. 2014; Babini et al. 2016; Mesak et al. 2018; Pérez-Iglesias et al. 2018 and 2019). In in situ studies, these ENAs have been observed in anurans in urban areas (Pollo et al. 2015); soybean plantations (Pollo et al. 2015; Borges et al. 2019b), areas of silviculture and ranching (Cruz-Esquivel et al. 2017), and mining operations (Pollo et al. 2017). The results of the present study thus provide further evidence that agricultural environments contribute to an increase in the frequency of ENAs.

The results of previous studies of MNs and other ENAs in leptodactylids exposed to environmental stressors are presented in Table S2 (Supplementary Material 2), including the data on the control groups (frogs in natural environments, similar to the ENP). In a control area, for example, Gonçalves et al. (2019) detected a frequency of $0.32 \pm 0.53$ micronucleated cells per 1000 erythrocytes in Physalaemus cuvieri, while Borges et al. (2019b) recorded a rate of $0.20 \pm 0.63$ in this species. In the present study, a frequency of $0.12 \pm 0.15$ micronucleated cells per 2000 erythrocytes was recorded in the $L$. fuscus control (ENP) specimens.

\section{Hepatic melanin}

A significantly smaller area of melanin was detected in the liver tissue of the L. fuscus specimens collected in the soybean plantation in comparison with those from the ENP. This type of cell plays a role in detoxification (Fanali et al. 2018) and other functions related to the immune system, as well neutralizing free radicals to protect the tissue from oxidative stress (Franco-Belussi et al. 2013). A number of previous studies have demonstrated the harmful effects of pesticides through the analysis of melanomacrophages in the liver of anurans (Paetow et al. 2012; Çakici 2015; Oliveira et al. 2016; Huespe et al. 2016; Pérez-Iglesias et al. 2016, 2019). In addition to pesticides, the action of agents such as Benzo[a]pyrene (Fanali et al. 2018), UV radiation (Franco-Belussi et al. 2016), fluorine (Bo et al. 2018), and cadmium (Wu et al. 2017) has already been demonstrated in the liver of anurans. De-Oliveira et al. (2017) also found that the agricultural matrix can also alter the area of melanomacrophages in anurans, with the exact level of response varying among different species. Drugs such as cyclophosphamide, flutamide, and testosterone cypionate may also influence the area of liver melanomacrophages (De-Oliveira et al. 2017).

The studies of Regnault et al. $(2014)$ and Fanali et al. $(2017,2018)$ demonstrated a significant reduction in the area of melonamacrophages in anurans exposed to Benzo[a]pyrene, a hydrocarbon considered to 
be a high-risk contaminant capable of inducing the formation of MNs (Fortin et al. 2015). This decrease in the area of melanomacrophages may be related to liver stress and hepatocyte apoptosis (Regnault et al. 2014). In an in situ study, Rohr et al. (2008) found that Atrazine and phosphate in the water caused a reduction in the area of melanomacrophages in anurans. In this same study, an experiment demonstrated that animals exposed to Atrazine suffered a significant reduction in melanomacrophages in comparison with the control group, which indicates that Atrazine suppresses the immune response exerted by the melanomacrophages in anurans.

However, other studies of pesticides have found an increase in the pigmented area of the liver of anurans exposed to these contaminants (Oliveira et al. 2016; Pérez-Iglesias et al. 2016, 2019). Pérez-lglesias et al. (2019) attributed this to a possible initial reaction to exposure to xenobiotics in the immune system, with the phagocytic properties of melanomacrophages contributing to the inflammatory process. These results reinforce the function of the organ and its physiological plasticity. Recent studies have shown that factors such as the hepatosomatic index and liver pigmentation vary due to the influence of land use (Gondim et al. 2020; Franco-Belussi et al. 2020). In a comparison of Leptodactylus macrosternum specimens from farmland and natural vegetation in Brazil's semi-arid zone, Gondim et al. (2020) found considerable variation in the hepatosomatic indices among sites, but no systematic different between agricultural and non-agricultural areas. In agricultural environments in the Cerrado, Franco-Belussi et al. (2020) found that amount of melanin and substances originating from hepatic cellular catabolism (lipofuscin and hemosiderin) varied among five anuran species, and between populations from areas with different types of land use. In the same study, L. fuscus had the smallest amount of melanin, and the abundance of the species was correlated negatively with the percentage of pasture planted in the landscape (Franco-Belussi et al. 2020). The extremely low percentage of melanin recorded in L. fuscus in the present study is consistent with these findings.

Overall, however, few data are available on the effects of agriculture on anuran melanomacrophages, not least because of the confounding effects of the multiple stressors found in these environments. Given this, there is a clear need for further research to better understand the response of these cells in anurans.

\section{Conclusions}

Based on the in situ analysis of biomarkers, the present study demonstrated the effects of soybean cultivation on the physiology of the anuran species Leptodactylus fuscus, in relation to the increase in the frequency of nuclear abnormalities of the erythrocytes and the reduction in liver melanin. The analysis of micronuclei and other nuclear erythrocyte abnormalities revealed an increase in genotoxic damage in the specimens from the soybean plantation in comparison with those from the natural habitat (control). The analysis of the hepatic melanin also demonstrated a reduction in the pigmented area in the specimens from the soybean plantation in comparison with the control. The evidence thus indicates that agriculture causes systemic effects in L. fuscus and that this process should be investigated further through the analysis of other parameters of the liver tissue, including cytochemical tests, such as hemosiderin and lipofuscin analyses, and enzymatic assays, to provide more conclusive insights into the phenomenon. 


\section{Declarations}

\section{Ethics approval and consent to participate}

For this study, licenses for the collection of specimens and animal experimentation were obtained from the Chico Mendes Institute for Biodiversity Conservation (ICMBio), under protocol 62687-1, and the Goiano Federal Institute Ethics Committee on the Use of Animals (CEUA/IFGoiano) under protocol number 6643030518.

\section{Consent for publication}

Not applicable.

\section{Availability of data and materials}

The datasets used and/or analysed during the current study are available from the corresponding author on reasonable request.

\section{Competing interests}

The authors declare that they have no competing interests.

\section{Funding}

This work was supported by the Brazilian Coordination for Higher Education Personnel Training (CAPES) Finance Code 001; The Brazilian Biodiversity Fund (FUNBIO); The National Council for Scientific and Technological Development (CNPq) (grant number \#304552/2019-4); The São Paulo State Research Foundation (FAPESP) (grant number \#2018/01078-7); The National Council for Scientific and Technological Development (CNPq) (grant number 477044/2013-1); and the Goiano Federal Institute.

\section{Author contributions}

Rhayane Alves Assis: Conceptualization, Methodology, Validation, Formal analysis, Investigation, Writing - Original Draft, Visualization. Wadson Rodrigues Rezende: Methodology, Validation, Investigation. Cirley Gomes Araújo dos Santos: Methodology, Validation, Investigation. Marcelino Benvindo-Souza: Methodology, Formal analysis, Writing - Review \& Editing, Visualization. Nathan Pereira Lima Amorim: Methodology, Validation, Investigation. Rinneu Elias Borges: Conceptualization, Methodology. Lilian Franco-Belussi: Writing - Review \& Editing, Visualization. Classius De-Oliveira: Writing - Review \& Editing. Lia Raquel de Souza Santos: Conceptualization, Methodology, Validation, Resources, Writing - Review \& Editing, Visualization, Supervision, Project administration, Funding acquisition. All authors read and approved the final manuscript.

\section{References}


1. Agius C (1980) Phylogenetic development of melano-macrophage centers in fish. J Zool 191:11-31. https://doi.org/10.1111/j.1469-7998.1980.tb01446.x.

2. Araújo APC, Mesak C, Montalvão MF, Freitas IN, Chagas TQ, Malafaia G (2019) Anti-cancer drugs in aquatic environment can cause cancer: Insight about mutagenicity in tadpoles. Sci Total Environ 650:2284-2293. https://doi.org/10.1016/j.scitotenv.2018.09.373.

3. Arcaute CR, Pérez-Iglesias JM, Nikoloff N, Natale GS, Soloneski S, Larramendy ML (2014) Genotoxicity evaluation of the insecticide imidacloprid on circulating blood cells of Montevideo tree frog Hypsiboas pulchellus tadpoles (Anura, Hylidae) by comet and micronucleus bioassays. Ecol Indic 45:632-639. https://doi.org/10.1016/j.ecolind.2014.05.034.

4. Babini MS, Bionda CL, Salas NE, Martino AL (2015) Health status of tadpoles and metamorphs of Rhinella arenarum (Anura, Bufonidae) that inhabit agroecosystems and its implications for land use. Ecotoxicol Environ Saf 118:118-125. https://doi.org/10.1016/j.ecoenv.2015.04.017.

5. Babini MS, Bionda CL, Salas NE, Martino AL (2016) Adverse effect of agroecosystem pond water on biological endpoints of common toad (Rhinella arenarum) tadpoles. Environ Monit Assess 188:459. https://doi.org/10.1007/s10661-016-5473-2.

6. Baršienè J, Bjornstad A, Rybakovas A, Šyvokienè J, Andreikènaitè L (2010) Environmental genotoxicity and cytotoxicity studies in mussels and fish inhabiting northern Atlantic zones impacted by aluminum industry. Ekologija 56:116-123. https://doi.org/ 10.2478/v10055-010-0017-5.

7. Benvindo-Souza M, Oliveira EAS, Assis RA, Santos CGA, Borges RE, Silva DM, Santos LRS (2020) Micronucleus test in tadpole erythrocytes: Trends in studies and new paths. Chemosphere 240:124910. https://doi.org/10.1016/j.chemosphere.2019.124910.

8. Blaustein AR, Han BA, Relyea RA, Johnson PTJ, Buck JC, Gervasi SS, Kats LB (2011) The complexity of amphibian population declines: understanding the role of co-factors in driving amphibian losses. Ann N Y Acad Sci 123:108- 119. https://doi.org/10.1111/j.1749-6632.2010.05909.x.

9. Bo X, Mu D, Wu M, Xiao H, Wang H (2018) The morphological changes and molecular biomarker responses in the liver of fluoride-exposed Bufo gargarizans larvae. Ecotoxicol Environ Saf 151:199205. https://doi.org/10.1016/j.ecoenv.2018.01.027.

10. Böll S, Schmidt B, Veith M, Wagner N, Rödder D, Weinmann C, Kirschey T, Loetters S (2013) Amphibians as indicators of changes in aquatic and terrestrial ecosystems following GM crop cultivation: a monitoring guideline. BioRisk 8:39-51. https://doi.org/10.3897/biorisk.8.3251.

11. Borges RE, Santos LRS, Assis RA, Benvindo-Souza M, Franco-Belussi L, De Oliveira C (2019a) Monitoring the morphological integrity of neotropical anurans. Environ Sci Pollut Res 26:2623-2634. https://doi.org/10.1007/s11356-018-3779-z.

12. Borges RE, Santos LRS, Benvindo-Souza M, Modesto RS, Assis RA, De Oliveira C (2019b) Genotoxic Evaluation in Tadpoles Associated with Agriculture in the Central Cerrado, Brazil. Arch Environ Contam Toxicol 77:22-28. https://doi.org/10.1007/s00244-019-00623-y.

13. Çakici Ö (2015) Histopathologic changes in liver and kidney tissues induced bycarbaryl in Bufotes variabilis (Anura: Bufonidae). Exp Toxicol Pathol 67:237-243. 
https://doi.org/10.1016/j.etp.2014.12.003.

14. Cañedo AM, Kefford BJ, Piscart C, Prat N, Schäfer RB, Schulz CJ (2013) Salinisation of rivers: an urgent ecological issue. Environ Pollut 173:157-167. https://doi.org/10.1016/j.envpol.2012.10.011.

15. Carvalho WF, Arcaute CR, Pérez-Iglesias JM, Laborde MRR, Soloneski S, Larramendy ML (2019) DNA damage exerted by mixtures of commercial formulations of glyphosate and imazethapyr herbicides in Rhinella arenarum (Anura, Bufonidae) tadpoles. Ecotoxicology 28:367-377.

https://doi.org/10.1007/s10646-019-02029-x.

16. Cruz-Esquivel A, Viloria-Rivas J, Marrugo-Negrete J (2017) Genetic damage in Rhinella marina populations in habitats affected by agriculture in the middle region of the Sinú River, Colombia. Environ Sci Pollut Res 24:27392-27401. https://doi.org/10.1007/s11356-017-0134-8.

17. Collins JP (2010) Amphibian decline and extinction: What we know and what we need to learn. Dis Aquat Organ 92: 93-99. https://doi.org/10.3354/dao02307.

18. De-Oliveira C, Franco-Belussi L, Fanali LZ, Santos LRS (2017) Use of Melanin-pigmented Cells as a New Tool to Evaluate Effects of Agrochemicals and Other Emerging Contaminants in Brazilian Anurans. In: Larramendy ML (ed) Ecotoxicology and Genotoxicology: Non-traditional Terrestrial Models. The Royal Society of Chemistry, London, pp 125-142.

19. Dias LCP, Pimenta FM, Santos AB, Costa MH, Ladle RJ (2016) Patterns of land use, extensification, and intensification of Brazilian agriculture. Glob Chang Biol 22:2887-2903. https://doi.org/10.1111/gcb.13314.

20. Fanali LZ, de Lacerda Valverde BS, Franco-Belussi, L, Provete DB, De Oliveira C (2017) Response of digestive organs of Hypsiboas albopunctatus (Anura: Hylidae) to benzo [a] pyrene. Amphib-reptil 38:175-185. http://dx.doi.org/10.1163/15685381-00003101.

21. Fanali LZ, Franco-Belussi L, Bonini-Domingos CR, De Oliveira C (2018) Effects of benzo[a]pyrene on the blood and liver of Physalaemus cuvieri and Leptodactylus fuscus (Anura: Leptodactylidae). Environ Pollut 237:93-102. https://doi.org/10.1016/j.envpol.2018.02.030.

22. Fenech M (2000) The in vitro micronucleus technique. MutatRes Genet Toxico/Environ Mutagen 455:81-95. https://doi.org/10.1016/S0027-5107(00)00065-8.

23. Ficetola GF, Maiorano L (2016) Contrasting effects of temperature and precipitation change on amphibian phenology, abundance and performance. Oecologia 6:457-463. https://doi.org/10.1007/s00442-016-3610-9.

24. Fishelson $L$ (2006) Cytomorphological alterations of the thymus, spleen, head kidney, and liver in cardinal fish (Apogonidae, Teleostei) as bioindicators of stress. J Morphol 267:57-69. https://doi.org/10.1002/jmor.10385.

25. Fortin F, Bonvalot Y, Pham TCV, Ouellet N, Ayotte P, Viau C, Lemieux N (2015) Biomarkers of genotoxicity measured in human lymphocytes exposed to benzo [a]pyrene: aneugenic effect, and involvement multiple primary DNA lesions. Integr Pharmacol Toxicol Genotoxicol 1:21-32. https://doi.org/10.15761/IPTG.1000106. 
26. Franco-Belussi L, Castrucci AMDL, De Oliveira C (2013) Responses of melanocytes and melanomacrophages of Eupemphix nattereri (Anura: Leiuperidae) to Nle4, D-Phe7-a-melanocyte stimulating hormone and lipopolysaccharides. Zoology 116:316-324. http://dx.doi.org/10.1016/j.zool.2013.06.003.

27. Franco-Belussi L, Skold HN, De Oliveira C (2016) Internal pigment cells respond to external UV radition in frogs. J Exp Biol 219:1378-1383. http://doi.org/0.1242/jeb.134973.

28. Franco-Belussi L, Fanali LZ, De Oliveira C (2018) UV-B affects the immune system and promotes nuclear abnormalities in pigmented and non-pigmented bullfrog tadpoles. J Photoch Photobi B Biol 180:109-117. https://doi.org/10.1016/j.jphotobiol.2018.01.022.

29. Franco-Belussi L, Provete DB, Borges RE, Oliveira C, Santos LRS (2020) Idiosyncratic liver alterations of five frog species to land use changes in the Brazilian Cerrado. PeerJ 8:e9751. https://doi.org/10.1101/837534.

30. Fijan N (2002) Morphogenesis of blood cell lineages in channel catfish. J Fish Biol 60:999-1014. https://doi.org/10.1111/j.1095-8649.2002.tb02424.x.

31. Frost DR (2019) Amphibian Species of the World: An Online Reference. Version 6.0 (July 2019). http://research.amnh.org/herpetology/amphibia/index.html. Accessed 17 November 2020.

32. García GC, Fontúrbel FR (2003) Propuestas para un desarrollo sostenible: Lago Titikaka por estrategas K. Editorial Publicaciones Integrales, La Paz.

33. Gatica EA, Almeida CA, Mallea MA, Corigliano CM, González P (2012) Water quality assessment, by statistical analysis, on rural and urban areas of Chocancharava River (Río Cuarto), Córdoba, Argentina. Environ Monit Assess 184:7257-7274. https://doi.org/10.1007/s10661-011-2495-7.

34. Gonçalves MW, Campos CBM, Godoy FR, Gambale PG, Nunes HF, Nomura F, Bastos RP, Cruz AD, Silva DM (2019) Assessing Genotoxicity and Mutagenicity of Three Common Amphibian Species Inhabiting Agroecosystem Environment. Arch Environ Contam Toxicol 77:409-420. https://doi.org/10.1007/s00244-019-00647-4.

35. Gondim PM, Rodrigues JFM, Cascon P (2020) Fluctuating Asymmetry and Organosomatic Indices in Anuran Populations in Agricultural Environments in Semi-arid Brazil. Herpetol Conserv Biol 15:354366.

36. Green FB, East AG, Salice CJ (2019) Will temperature increases associated with climate change potentiate toxicity of environmentally relevant concentrations of chloride on larval green frogs (Lithobates clamitans)? Sci Total Environ 682:282-290.

https://doi.org/10.1016/j.scitotenv.2019.05.018.

37. Hoffman D, Rattner B, Burton JRG, Cairns JRJ (2003) Handbook of ecotoxicology, second ed. Lewis Publishers, Boca Raton.

38. Hoffman DJ, Rattner BA, Burton GA, Cairns Jr J (2010) Handbook of ecotoxicology. CRC Press, London, New York, Washington.

39. Huespe I, Cabagna-Zenklusen M, Curi LM, Peltzer P, Attademo MA, Villafane N, Lajmanovich R (2016) Melanomacrófagos hepáticos y actividad de la enzima glutation s-transferasa en Leptodacty/us 
chaquensis (Anura, Leptodactylidae) como biomarcadores de estrés oxidativo por la exposición a clorpirifos. Acta Biolo Colomb 22: 234-237. http://dx.doi.org/10.15446/abc.v22n2.60823.

40. Instituto Brasileiro de Geografia e Estatística (IBGE) (2019) Produção agrícola - Lavoura temporária. https://cidades.ibge.gov.br/brasil/go/rioverde/pesquisa/14/10193?tipo=ranking\&indicador=10368. Accessed 12 July 2019.

41. Instituto Chico Mendes de Conservação da Biodiversidade (ICMBio) (2019) Parque Nacional das Emas. http://www.icmbio.gov.br/portal/visitacao1/unidades-abertas-a-visitacao/204-parquenacional-das-emas. Accessed 12 July 2019.

42. Instituto Mauro Borges de Estatísticas e Estudos Socioeconômicos (IMB) (2019) Análises conjunturiais - Balança comercial - COMEX.

http://www.imb.go.gov.br/files/docs/releases/comex/2019/comex201905.pdf. Accessed 12 July 2019.

43. Josende ME, Tozetti AM, Alalan MT, Mathies-Filho V, Ximenez SS, Silva-Júnior FMR, Martins SE (2015) Genotoxic evaluation in two amphibian species from Brazilian subtropical wetlands. Ecol Indic 49:83-87. https://doi.org/10.1016/j.ecolind.2014.10.007.

44. Lajmanovich RC, Cabagna-Zenklusen MC, Attademo AM, Junges CM, Peltzer PM, Bassó A, Lorenzatti E (2014) Induction of micronuclei and nuclear abnormalities in tadpoles of the common toad (Rhinella arenarum) treated with the herbicides Liberty ${ }^{\circledR}$ and glufosinate-ammonium. Mutat Res 769:7-12. https://doi.org/10.1016/j.mrgentox.2014.04.009.

45. Leeb C, Brühl C, Theissinger K (2020) Potential pesticide exposure during the post-breeding migration of the common toad (Bufo bufo) in a vineyard dominated landscape. Sci Total Environ 706:134430. https://doi.org/10.1016/j.scitotenv.2019.134430.

46. Lipinski VM, Santos TG, Schuch AP (2016) An UV-sensitive anuran species as an indicator of environmental quality of the Southern Atlantic Rainforest. J Photochem Photobiol B 165:174-181. https://doi.org/10.1016/j.jphotobiol.2016.10.025.

47. Marquis O, Miaud C, Ficetola GF, Bocher A, Mouchet F, Guittonneau S, Devaux A (2009) Variation in genotoxic stress tolerance among frog populations exposed to UV and pollutant gradients. Aquat Toxicol 95:152-161. https://doi.org/10.1016/j.aquatox.2009.09.001.

48. Mesak C, Mendes BO, Ferreira RO, Malafaia G (2018) Mutagenic assessment of Lithobates catesbeianus tadpoles exposed to the 2,4-D herbicide in a simulated realistic scenario. Environ Sci Pollut Res 25:15235-15244. https://doi.org/10.1007/s11356-018-1979-1.

49. NASA Official (2020) NASA Prediction Of Worldwide Energy Resources. https://power.larc.nasa.gov/\#dataaccess. Accessed 08 July 2020.

50. Oliveira CR, Fraceto LF, Rizzi GM, Salla RF, Abdalla FC, Costa MJ, Silva-Zacarin ECM (2016) Hepatic effects of the clomazone herbicide in both its free form and associated with chitosan-alginate nanoparticles in bullfrog tadpoles. Chemosphere 149:304-313.

https://doi.org/10.1016/j.chemosphere.2016.01.076. 
51. Paetow LJ, McLaughlin D, Cue RI, Pauli BD, Marcogliese DJ (2012) Effects of herbicides and the chytrid fungus Batrachochytrium dendrobatidis on the health of post-metamorphic northern leopard frogs (Lithobates pipiens). Ecotoxicol Environ Saf 80:372-380. https://doi.org/10.1016/j.ecoenv.2012.04.006.

52. Pérez-Iglesias JM, Franco-Belussi L, Moreno L, Tripole S, De Oliveira C, Natale GS (2016) Effects of glyphosate on hepatic tissue evaluating melanomacrophages and erythrocytes responses in neotropical anuran Leptodacty/us latinasus. Environ Sci Pollut Res 23:9852-9861. https://doi.org/10.1007/s11356-016-6153-z.

53. Pérez-Iglesias JM, Natale GS, Solonesi S, Larramendy ML (2018) Are the damaging effects induced by the imazethapyr formulation Pivot ${ }^{\circledR} \mathrm{H}$ in Boana pulchella (Anura) reversible upon ceasing exposure? Ecotoxicol Environ Saf 148:1-10. https://doi.org/10.1016/j.ecoenv.2017.10.009.

54. Pérez-Iglesias JM, Franco-Belussi L, Natale GS, De Oliveira C (2019) Biomarkers at different levels of organisation after atrazine formulation (SIPTRAN 500SC ${ }^{\circledR}$ ) exposure in Rhinella schineideri (Anura: Bufonidae) Neotropical tadpoles. Environ Pollut 244:733-746. https://doi.org/10.1016/j.envpol.2018.10.073.

55. Pérez-Iglesias JM, Brodeur JC, Larramendy ML (2020) An imazethapyr-based herbicide formulation induces genotoxic, biochemical, and individual organizational effects in Leptodacty/us latinasus tadpoles (Anura: Leptodactylidae). Environ Sci Pollut Res 27:2131-2143. https://doi.org/10.1007/s11356-019-06880-7.

56. Pignati WA, Lima FANS, Lara SS, Correa MLM, Barbosa JR, Leão LHC (2017) Distribuição espacial do uso de agrotóxicos no Brasil: uma ferramenta para a Vigilância em Saúde. Ciên Saúde Coletiva 22:3281-3293. http://dx.doi.org/10.1590/1413-812320172210.17742017.

57. Pimentel D (1995) Amounts of pesticides reaching target pests: environmental impacts and ethics. $J$ Agric Environ Ethics 8:17-29. https://doi.org/10.1007/BF02286399.

58. Pollo FE, Bionda CL, Salinas ZA, Salas NE, Martino AL (2015) Common toad Rhinella arenarum (Hensel, 1867) and its importance in assessing environmental health: test of micronuclei and nuclear abnormalities in erythrocytes. Environ Monit Assess 187:581. https://doi.org/10.1007/s10661-0154802-1.

59. Pollo FE, Grenat PR, Salinas ZA, Otero MA, Salas NE, Martino AL (2017) Evaluation in situ of genotoxicity and stress in South American common toad Rhinella arenarum in environments related to fluorite mine. Environ Sci Pollut Res 24:18179-18187. https://doi.org/10.1007/s11356-017-94792.

60. Pollo FE, Grenat PR, Otero MA, Babini S, Salas NE, Martino AL (2018) Evaluation in situ of genotoxic and cytotoxic response in the diploid/polyploid complex Odontophrynus (Anura: Odontophrynidae) inhabiting agroecosystems. Chemosphere 216:306-312.

61. Prado VHM, Rossa-Feres DC (2014) Multiple Determinants of Anuran Richness and Occurrence in an Agricultural Region in South-Eastern Brazil. Environ Manage 53:823-837. https://doi.org/10.1007/s00267-014-0241-y. 
62. Prieto-García F, Baez Ramirez OA, Scout W, Gaytán Oyarzún JC, Zúñiga Estrada A (2007) Toxicidad y teratogénesis por arsénico en el pez cebra [Danio rerio]. Rev de Toxicol 24:18-22.

63. Regnault C, Worms IA, Oger-Desfeux C, Melo-de-Lima C, Veyrenc S, Bayle ML, Reynaud S (2014) Impaired liver function in Xenopus tropicalis exposed to benzo[a]pyrene: transcriptomic and metabolic evidence. BMC Genomics 15:666. https://doi.org/10.1186/1471-2164-15-666.

64. Rohr JR, Schotthoefer AM, Raffel TR, Carrick HJ, Halstead N, Hoverman JT, Schoff PK (2008) Agrochemicals increase trematode infections in a declining amphibian species. Nature 455:1235. https://doi.org/10.1038/nature07281.

65. Santos LRS, Franco-Belussi L, Zieri R, Borges RE, De Oliveira C (2014) Effects of thermal stress on hepatic melanomacrophages of Eupemphix nattereri (Anura). Anat Rec 297:864-875. https://doi.org/10.1002/ar.22884.

66. Silva FR, Candeira CP, Rossa-Feres DC (2012a) Dependence of anuran diversity on environmental descriptors in farmland ponds. Biodivers Conserv 21:1411-1424. https://doi.org/10.1007/s10531012-0252-z.

67. Silva FR, Oliveira TAL, Gibbs JP, Rossa-Feres DC (2012b) An experimental assessment of landscape configuration effects on frog and toad abundance and diversity in tropical agro-savannah landscapes of southeastern Brazil. Landsc Ecol 27:8796. https://doi.org/10.1007/s10980-011-96707 .

68. Stuart SN, Chanson JS, Cox NA, Young BE, Rodrigues ASL, Fischman DL, Waller RW (2004) Status and trends of amphibian declines and extinctions worldwide. Science 306:1783-1786. https://doi.org/10.1126/science.1103538.

69. Sugai JLMM, Terra JS, Ferreira VL (2012) Diet of Leptodactylus fuscus (Amphibia: Anura: Leptodactylidae) in the Pantanal of Miranda river, Brazil. Biota Neotrop 12:99-104. http://dx.doi.org/10.1590/S1676-06032012000100008.

70. Vera-Candioti J, Soloneski S, Larramendy ML (2013) Single-cell gel electrophoresis assay in the ten spotted live-bearer fish, Cnesterodon decemmaculatus (Jenyns, 1842), as bioassay for agrochemicalinduced genotoxicity. Ecotoxicol Environ Saf 98:368-373. https://doi.org/10.1016/j.ecoenv.2013.08.011.

71. Vredenburg VT, Knapp RA, Tunstall TS, Briggs CJ (2010) Dynamics of an emerging disease drive large-scale amphibian population extinctions. Proc Natl Acad Sci 107:9689-9694. https://doi.org/10.1073/pnas.0914111107.

72. Wu C, Zhang Y, Chai L, Wang H (2017) Histological changes, lipid metabolism and oxidative stress in the liver of Bufo gargarizans exposed to cadmium concentrations. Chemosphere 179:337-346. https://doi.org/10.1016/j.chemosphere.2017.03.131.

73. Wynn A, Heyer WR (2001) Do geographically widespread species of tropical amphibians exist? An estimate of genetic relatedness within the neotropical frog Leptodactylus fuscus (Anura, Leptodactylidae). Trop Zool 14:255-285. https://doi.org/10.1080/03946975.2001.10531157. 
74. Zuasti A, Jara JR, Ferre C, Solano F (1989) Occurrence of melanin granules and melanosynthesis in the kidney of Sparus auratus. Pigment Cell Melanoma Res 2:93-99. https://doi.org/10.1111/j.16000749.1989.tb00168.x.

\section{Tables}

Table 1 Physical-chemical parameters of the water samples evaluated in situ in the two study environments in southwestern Goiás.

\begin{tabular}{|lll|}
\hline Parameter & Emas National Park & Soybean plantation \\
\hline Water temperature & $23.2^{\circ} \mathrm{C}$ & $35.7^{\circ} \mathrm{C}$ \\
\hline $\mathrm{pH}$ & 7.41 & 5.38 \\
\hline Conductivity & $2.56 \mu \mathrm{S}$ & $3.70 \mu \mathrm{S}$ \\
\hline Total dissolved solids & $1.74 \mathrm{ppm}$ & $20.0 \mathrm{ppm}$ \\
\hline Salinity & $0.01 \mathrm{psu}$ & $1.31 \mathrm{psu}$ \\
\hline Resistivity & 3.20 & 24.8 \\
\hline Dissolved oxygen & $101.9 \%$ & $76.1 \%$ \\
\hline
\end{tabular}

Table 2 Mean \pm SD (standard deviation) frequency of micronuclei (MN) and other erythrocyte nuclear abnormalities (ENAs) in the erythrocytes (in 2000 cells/animal) of L. fuscus collected in the protected area (ENP $=$ Emas National Park) and the soybean plantation in Rio Verde, Goiás, Brazil.

\begin{tabular}{|lll|}
\hline ENAs & ENP $(\boldsymbol{n}=10)$, mean \pm SD & Soybean plantation $(\mathbf{n = 1 0})$, mean $\pm S D$ \\
\hline Micronucleus & $0.12 \pm 0.15$ & $0.43 \pm 0.27^{*}$ \\
\hline Reniform nucleus & $0.21 \pm 0.24$ & $0.84 \pm 0.30^{*}$ \\
\hline Lobed nucleus & $0.21 \pm 0.19$ & $0.71 \pm 0.45^{\star}$ \\
\hline Notched nucleus & $0.67 \pm 0.29$ & $0.86 \pm 0.52$ \\
\hline Anucleated cell & $0.10 \pm 0.18$ & $0.25 \pm 0.24$ \\
\hline Nuclear bud & $0.36 \pm 0.37$ & $0.49 \pm 0.39$ \\
\hline Segmented nucleus & $0.46 \pm 0.38$ & $0.37 \pm 0.29$ \\
\hline Binucleated cell & $0.03 \pm 0.09$ & $0.04 \pm 0.15$ \\
\hline
\end{tabular}

${ }^{*} \mathrm{p}<0.05$, significant difference according to Student's $T$ test and Mann-Whitney U test (data transformed into Log10). 


\section{Figures}

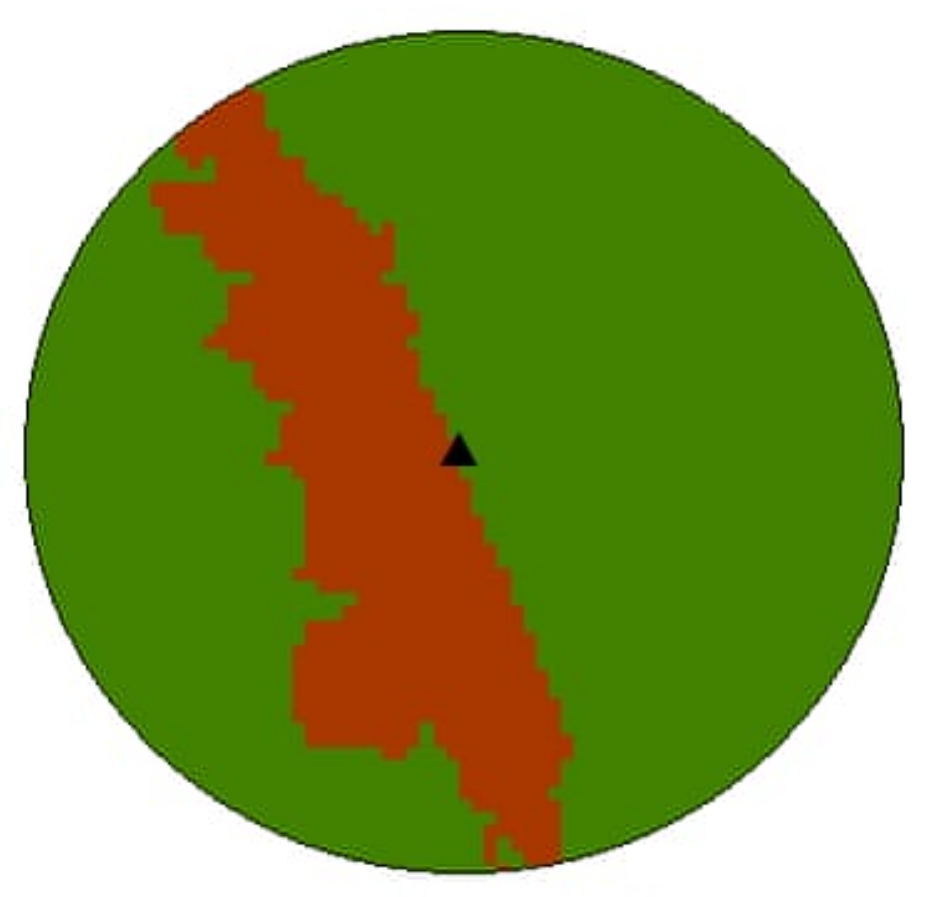

Emas National Park

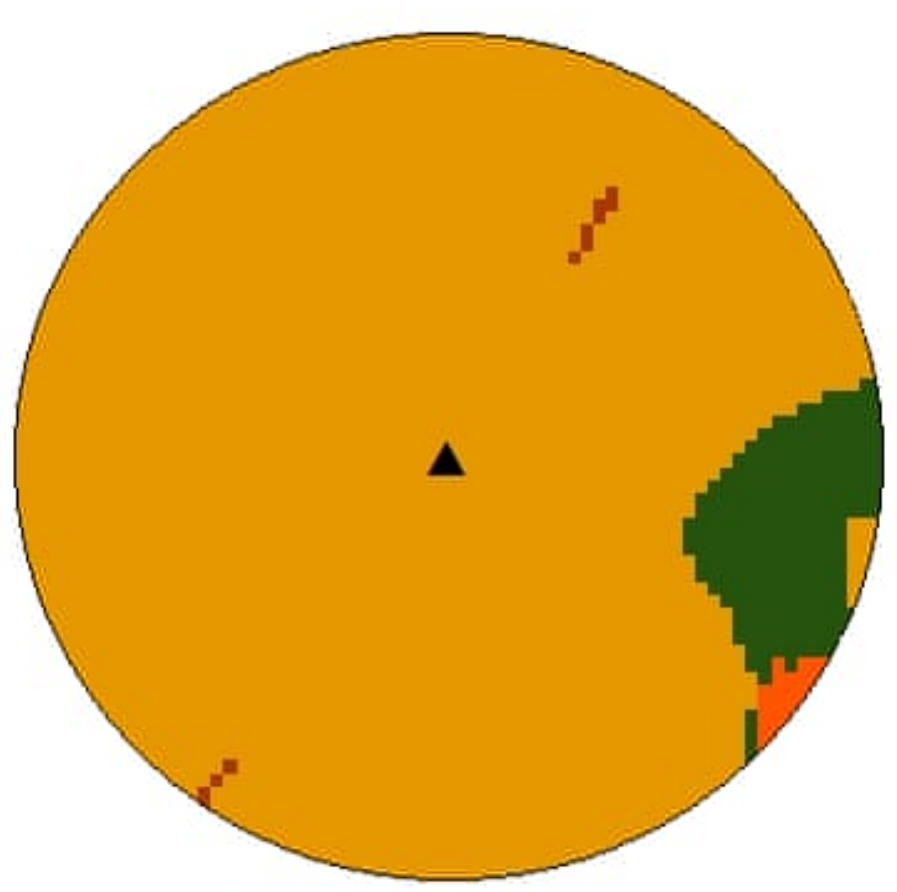

Soybean Plantation
Forest Formation

Grassland

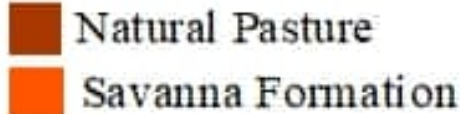

Savanna Formation
Annual and Perennial Crop

$\Delta$ Sampling Point

\section{Figure 1}

Characterization of anuran collection points in the Emas National Park and Soybean Plantation in Rio Verde. Classification according to Google Earth for the year 2018. Radius of $1 \mathrm{~km}$ 


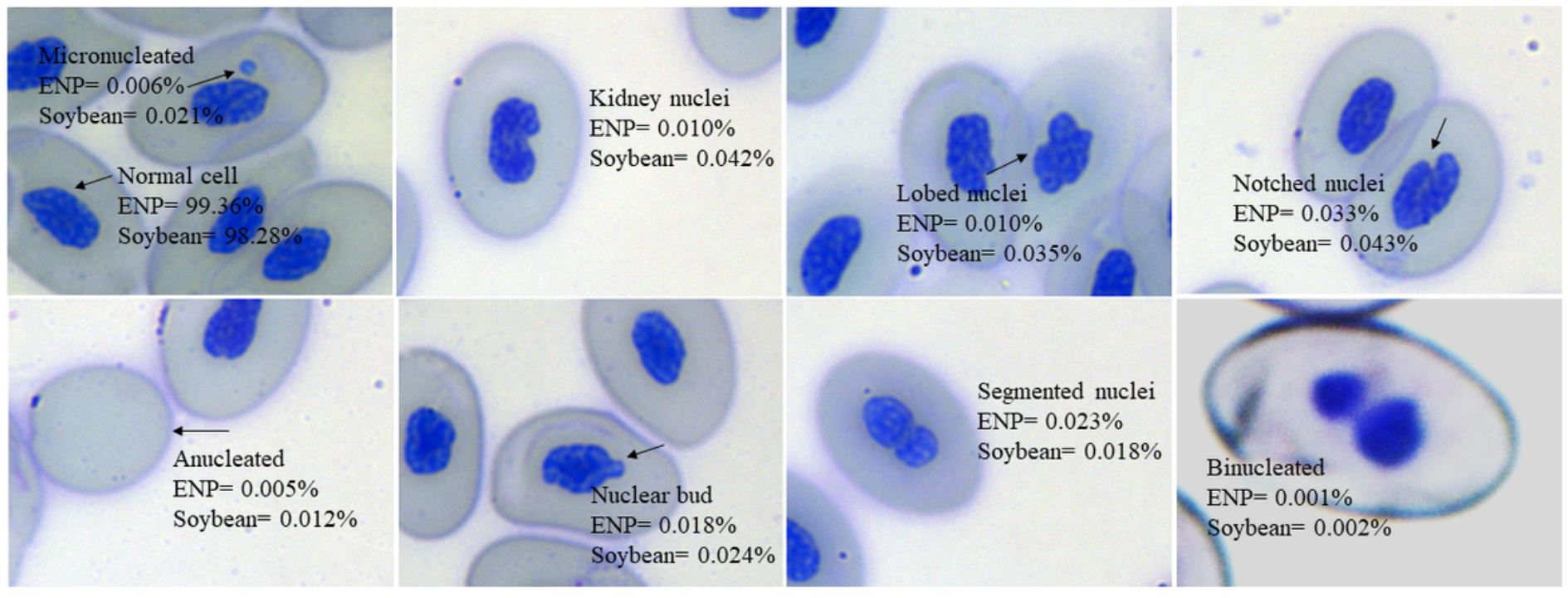

\section{Figure 2}

Approximate frequencies (\%) of each cell type in 2000 erythrocytes of L. fuscus collected in Emas National Park (ENP) and in soybean plantation (stained with Giemsa and magnified 1000x) (data transformed into Log10)

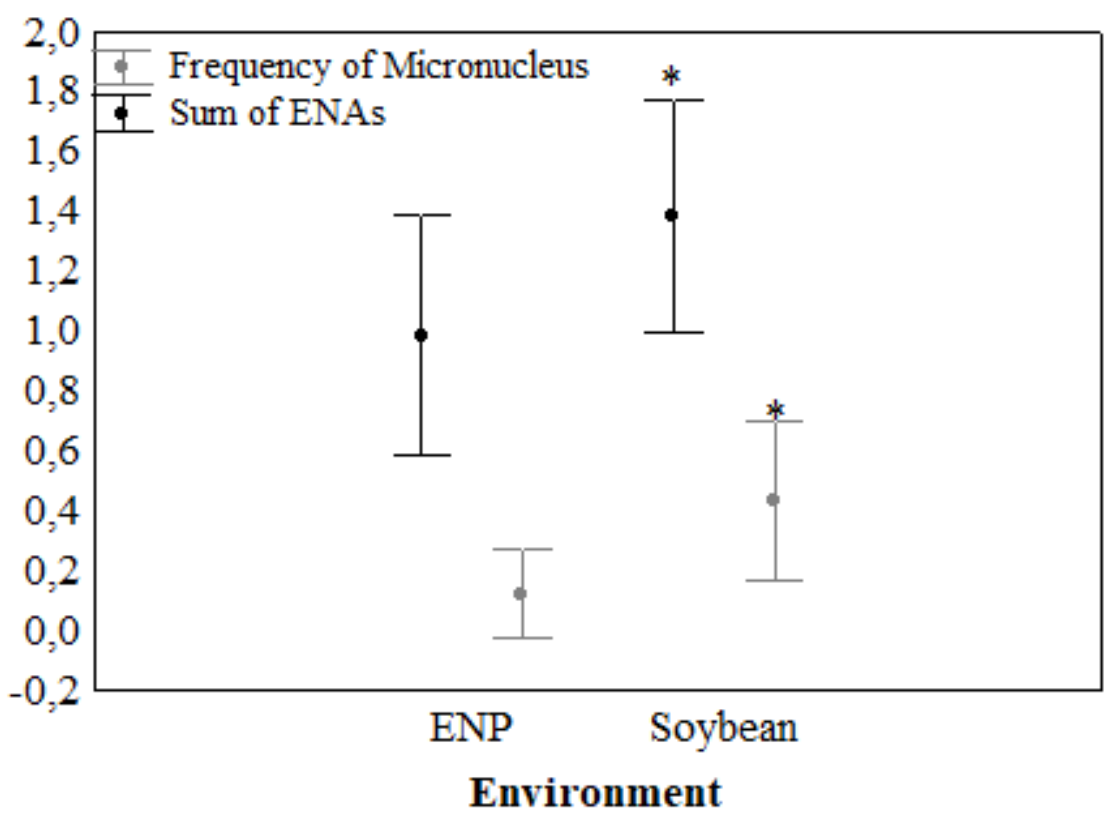

Figure 3 
Frequency of micronuclei and other erythrocyte nuclear abnormalities (ENAs) in the L. fuscus specimens collected in the Emas National Park (ENP) and the soybean plantation in Rio Verde. The data are presented as the means (circles) and standard deviations (vertical bars). The asterisks represent a significant difference between the two environments according to Student's t (data Log10 transformed)
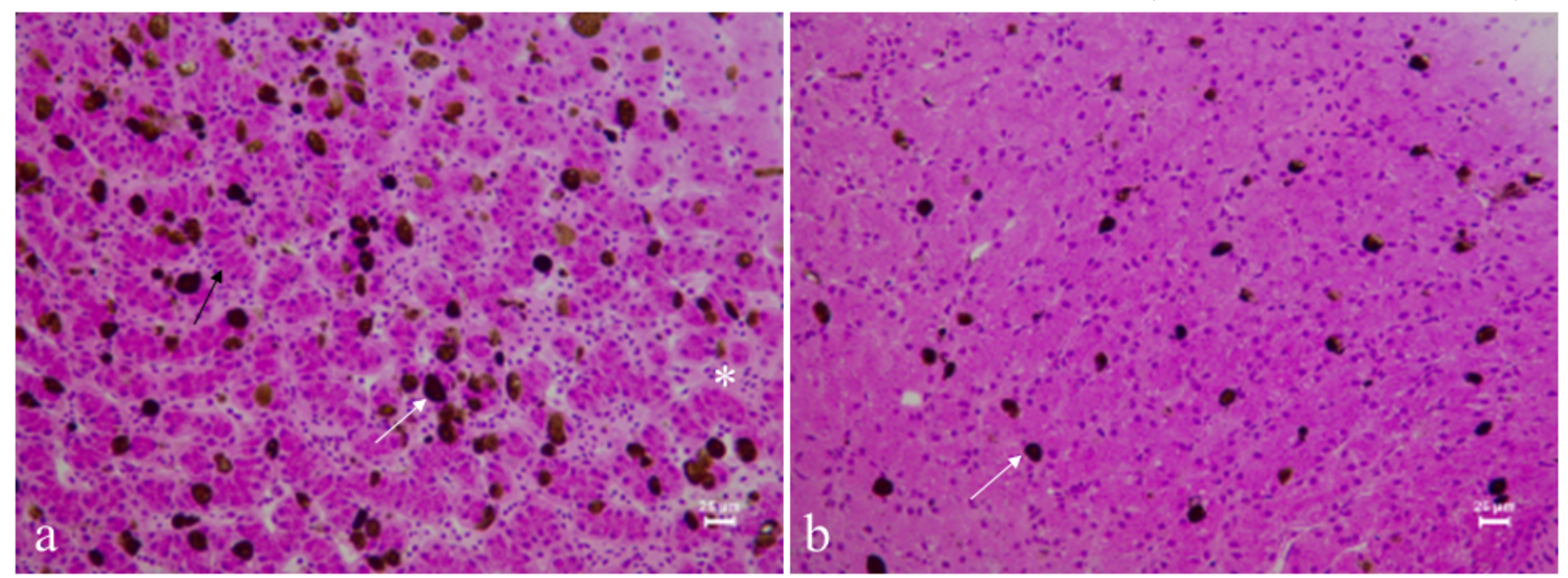

\section{Figure 4}

Photomicrograph of the liver tissue of $L$. fuscus showing the amount and occupation of melanomacrophages containing melanin (white arrows). a specimen collected in the Emas National Park, b specimen collected in the soybean plantation in Rio Verde. It is possible to observe a smaller pigmented area in b. Scale bars $=25 \mu \mathrm{m}$. Stain: HE. Black arrows = hepatocytes; asterisks = sinusoids

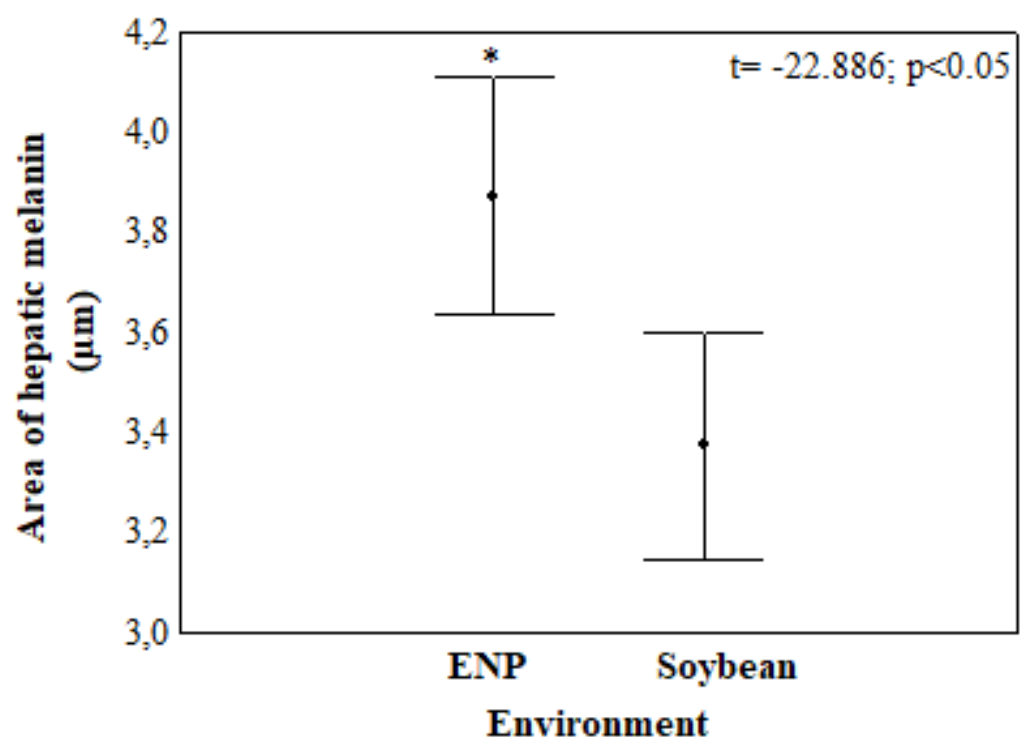

\section{Figure 5}

Area occupied by melanin in the liver tissue of the L. fuscus specimens collected in the soybean plantation and the natural vegetation (ENP: Emas National Park). The data are presented as means (circles) and standard deviations (vertical bars). The asterisk indicates a significant difference in the area 
of melanomacrophages between the two environments according to Student's $t$ (data Log10 transformed)

\section{Supplementary Files}

This is a list of supplementary files associated with this preprint. Click to download.

- ESM1.docx

- ESM2.docx 